Article

\title{
Response of Aquatic Plants and Water Quality to Large-Scale Nymphoides peltata Harvest in a Shallow Lake
}

\author{
Jinge Zhu ${ }^{1}$, Zhaoliang Peng ${ }^{1}$, Xin Liu ${ }^{1,2}$, Jiancai Deng ${ }^{1}$, Yihui Zhang ${ }^{1}$ and Weiping Hu ${ }^{1, *}$ \\ 1 State Key Laboratory of Lake Science and Environment, Nanjing Institute of Geography and Limnology, \\ Chinese Academy of Sciences, Nanjing 210008, China; jgzhu@niglas.ac.cn (J.Z.); zlpeng@niglas.ac.cn (Z.P.); \\ liuxin_adam@sina.com (X.L.); jcdeng_nj@126.com (J.D.); yhzhang@niglas.ac.cn (Y.Z.) \\ 2 Graduate School of the Chinese Academy of Sciences, Beijing 100039, China \\ * Correspondence: wphu@niglas.ac.cn
}

Received: 22 November 2018; Accepted: 28 December 2018; Published: 4 January 2019

\begin{abstract}
Aquatic plant harvest has been widely considered a plant management measure, as it can physically remove the targeted plants quickly and efficiently. Few empirical studies have examined the effects of harvesting on water quality or the aquatic plant community in a complete lake ecosystem. A large area $\left(196 \mathrm{~km}^{2}\right)$ of floating-leaved Nymphoides peltata was harvested in Lake Taihu in 2013. The effects of harvesting on the coverage and biomass of $N$. peltata and on the submerged plant community were evaluated. The quantities of nitrogen and phosphorus removed by harvesting were calculated. Harvesting caused an immediate reduction in N. peltata coverage, and its coverage in the following year ranged from $29.2 \%$ to $95.1 \%$. Wave conditions and interspecific competition were the main factors that influenced the response of the submerged plant community to N. peltata harvesting. Harvesting may favor the dominance of Hydrilla verticillata, which expands quickly at an average growth rate of $53 \pm 14 \mathrm{~g} \mathrm{~m}^{-2}$ day ${ }^{-1}$. Harvesting a large amount of $N$. peltata has a positive effect on total nitrogen $(\mathrm{TN})$, ammonium nitrogen $\left(\mathrm{NH}_{3}-\mathrm{N}\right)$, and chemical oxygen demand $\left(\mathrm{COD}_{\mathrm{Mn}}\right)$ control but can lead to different consequences (e.g., increase in total phosphorus (TP) and algal concentration).
\end{abstract}

Keywords: biomanipulation; ecosystem approach; vegetation; ecological engineering; restoration

\section{Introduction}

The excessive growth of aquatic plants can have negative effects on the lake ecosystem and water quality [1,2]. Large aggregations of plants covering the water surface limit light penetration and prevent water aeration. Dead plant parts deposited on the bottom of lakes release nutrients into the lake water when they decay [3]. Therefore, maintaining the aquatic vegetation density and biomass at a beneficial level becomes important for lake ecosystem management. Aquatic plant harvest has been widely considered as a plant management measure because it removes the targeted plant bodies quickly and efficiently. Furthermore, the nutrients contained in the plant tissues are also removed from the ecosystem, which reduces nutrient accumulation in the water column and sediments [4].

Previous studies have focused on the variation in plant morphology, propagation, and biomass allocation that occur because of harvesting. The harvested species include submerged plants, e.g., Potamogeton crispus [5], Ranunculus peltatus [6], Elodea nuttallii [7], and Hydrilla verticillata [4], and floating-leaved plants, e.g., Trapa bispinosa [8]. These studies are generally controlled experiments conducted in laboratories, small ponds, or enclosures. In addition, the beneficial biomass for macrophyte management has been evaluated via graphical models $[9,10]$, and these studies have provided advice for the management of macrophytes in shallow lakes. However, harvesting 
applications have been rare, and details of large-scale harvesting practices and the responses of the lake ecosystems are unclear. This is mainly because the environmental conditions of harvest experiments conducted in a laboratory or small pond are extremely different from those of a large lake. In lakes, water exchange and plant seed drift are less restricted owing to considerable water flow and wave disturbance. Furthermore, lake ecosystems have larger temporal and spatial scales than those of controlled experiments, in addition to constant intra- and interspecies competition among aquatic plants. In lake ecosystems, the ecological feedback mechanism is an important driving force for macrophyte community structure succession and biomass allocation [11]. As the environment changes, some species fail to establish, whereas other species colonize and grow to nuisance levels, often with negative consequences on plant community composition and ecosystem functions [12].

Lake Taihu is the third largest freshwater lake in China. Submerged and floating-leaved aquatic macrophytes are especially abundant in the eastern part of the lake [13-15], where floating-leaved macrophytes cover more than half of the macrophyte-dominated area. In some areas, floating-leaved macrophytes (Nymphoides peltata) occupy more than $70 \%$ of the water surface in summer and autumn, preventing water aeration and obstructing light from the water column. Furthermore, floating-leaved macrophytes probably uptake nutrients from nutrient-enriched sediments of the lake via root systems [16]. Tissue nitrogen and phosphorus release by healthy plants and from decaying plants result in higher water column N and P [17], therefore decreasing water quality. To restore the lake ecosystem and alleviate eutrophication, the lake management institution launched a tentative aquatic plant harvest across an area of $196 \mathrm{~km}^{2}$ beginning in 2013. As no such large-scale harvesting of aquatic plants has been reported before, observation and assessment are being conducted to monitor the effects on the lake ecosystem and to improve the effectiveness of the harvest.

The objectives of this study were: (1) to investigate the response of N. peltata and submerged aquatic vegetation to harvesting; (2) to evaluate the effects of harvesting on the water quality; and (3) to provide informed advice on large-scale harvesting of freshwater macrophytes.

\section{Method}

\subsection{Study Area}

Lake Taihu $\left(30.93^{\circ}-31.55^{\circ} \mathrm{N}, 119.88^{\circ}-120.6^{\circ} \mathrm{E}, \mathrm{WGS} 84\right)$, a large (surface area $\left.2338 \mathrm{~km}^{2}\right)$, shallow lake (maximum depth $2.6 \mathrm{~m}$, mean depth $1.9 \mathrm{~m}$ ), is dominated by a subtropical monsoon climate, located in the southern part of the Yangtze River Delta, one of the most densely populated regions in China. The topography of the lake bottom is quite flat, with a mean declivity of $0^{\circ} 0^{\prime} 19.66^{\prime \prime}$ [13]. Lake Taihu has great heterogeneity in water quality and ecotypes (e.g., macrophyteand phytoplankton-dominated ecotypes) [18]. In this study, the aquatic plant harvesting was carried out in the macrophyte-dominated area (Figure 1).

According to the spatial differentiation of the aquatic plant community, the harvest area was divided into six zones, denoted as Z1-Z6 (Figure 1). Potamogeton malaianus was the most widespread species in Lake Taihu and was the dominant submerged plant in Z1, Z3, Z4, and Z6 (Table 1). The dominant species in Z2 and Z5 were Potamogeton maackianus and Hydrilla verticillata, respectively. The second-most dominant species were Myriophyllum verticillatum for Z1, Z2, and Z3; H. verticillata for Z4 and Z6; and P. malaianus for Z5. The dominant floating-leaved plant species in these zones was N. peltata, which covered the six zones in different proportions. Some Trapa bispinosa was observed in $\mathrm{Z} 2$ and Z5, but its coverage and biomass were extremely low. The wave conditions in Lake Taihu were spatially diverse [19]; for the six zones, the wave conditions were ranked according to three levels (strong $>$ moderate $>$ weak) (Table 1 ). 

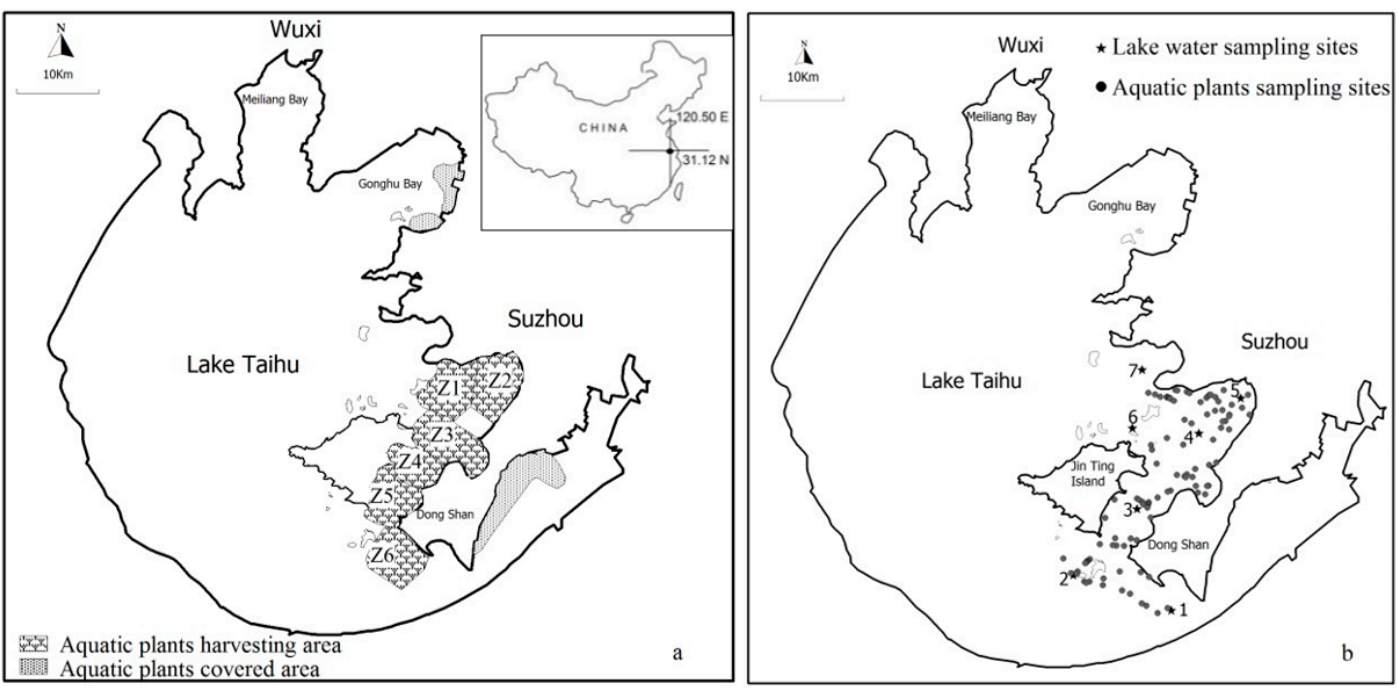

Figure 1. Aquatic plant harvesting area (a) and sampling sites (b) for water quality and aquatic plants.

Table 1. Wave conditions and dominant aquatic plant species of the six zones.

\begin{tabular}{|c|c|c|c|c|c|}
\hline Zones & $\begin{array}{c}\text { Area } \\
\left(\mathbf{k m}^{2}\right)\end{array}$ & $\begin{array}{c}\text { Wave } \\
\text { Conditions }\end{array}$ & $\begin{array}{l}\text { Harvesting Start } \\
\text { and End Date }\end{array}$ & $\begin{array}{c}\text { Dominant } \\
\text { Submerged Plant }\end{array}$ & $\begin{array}{c}\text { Secondary } \\
\text { Dominant } \\
\text { Submerged Plant }\end{array}$ \\
\hline Zone 1 (Z1) & 24.63 & strong & 3-26 May & P. malaianus & M. verticillatum \\
\hline Zone 2 (Z2) & 35.90 & moderate & 3-30 May & P. maackianus & M. verticillatum \\
\hline Zone $3(\mathrm{Z3})$ & 36.44 & strong & 5-27 May & P. malaianus & M. verticillatum \\
\hline Zone 4 (Z4) & 26.32 & moderate & 5-22 May & P. malaianus & H. verticillata \\
\hline Zone 5 (Z5) & 33.12 & weak & 5 May-13 June & H. verticillata & P. malaianus \\
\hline Zone 6 (Z6) & 33.81 & moderate & 26 August-14 September & P. malaianus & H. verticillata \\
\hline
\end{tabular}

\subsection{Study Species and Aquatic Vegetation Harvesting}

Nymphoides peltata is a widespread aquatic species that occurs in a wide range of climates and habitats, especially in temperate regions of the northern hemisphere [20]. Although N. peltata is rare and on the red list in some areas [21], it is a nuisance species for boating and swimming and provides minimal benefits to lake restoration in China [15] and some other areas, such as Sweden [22], North America [23], and New Zealand [24]. In this study, the target harvest species was N. peltata, which occupied more than half of the lake's water surface. Harvesting was carried out with machines because the harvest area was extensive, and mechanical harvesting cut costs and increased efficiency.

In this study, the cut depth was limited to $0.4 \mathrm{~m}$ to avoid destroying the submerged vegetation covered by $N$. peltata. However, it was impossible to separate the two types of vegetation during harvesting because, in some areas, the combination of floating $N$. peltata and submerged vegetation had formed a canopy near the surface. Therefore, a small amount of $P$. malaianus and $H$. verticillata was harvested. Harvesting in the study area began in 2013 (Table 1).

\subsection{Aquatic Vegetation Coverage and Biomass Survey}

A total of 114 sites $(16,25,16,10,20$, and 27 for Z1, Z2, Z3, Z4, Z5, and Z6, respectively) were used to monitor aquatic plants (Figure 1). Sampling sites were selected according to aquatic plant distribution, with the aim of sampling the plant distribution area as evenly as possible. At each site, the vegetation was manually extracted using a vegetation clip with an open mouth of $0.25 \mathrm{~m} \times 0.4 \mathrm{~m}$. Sampled plants were rinsed in the lake water and identified to species level. The biomass of each 
species was measured as wet weight in $\mathrm{kg} \mathrm{m}^{-2}$. To evaluate the distribution and spread of certain submerged species in each zone, the frequency of occurrence was determined and calculated as follows:

$$
\text { Frequency of occurrence }=\frac{\text { Number of sites where a species occurred }}{\text { Total number of sites }} \times 100 \%
$$

The floating-leaved N. peltata was visible to the naked eye, therefore its distribution and spread was determined as plant coverage. To measure the coverage, the sampling boat with a track-recording GPS moved slowly around the boundary of N. peltata and obtained the area of each patch, and the total area of N. peltata in each zone was calculated. Coverage of N. peltata was calculated as follows:

$$
\text { Coverage }=\frac{\text { Total area of } N \text {.peltata in } Z_{i}}{\text { Area of } Z_{i}} \times 100 \%
$$

Because most of the plant species in Lake Taihu will enter a phase of rapid growth between May and September, the observations during this phase were performed monthly. In this study, aquatic vegetation was investigated in May, June, July, August, October, and November 2013; January, March, April, June, July, August, September, October, and November 2014; and January, March and May 2015.

\subsection{Physical and Chemical Properties}

Water quality data were collected from 2011 to 2013 to evaluate the chemical properties before harvesting. These samples were collected and analyzed by the Taihu Lake Laboratory Ecosystem Research Station $\left(Z_{i}\right.$, Nanjing Institute of Geography and Limnology, Chinese Academy of Sciences (Figure $1 b)$. These data include the concentrations of total nitrogen $(\mathrm{TN})$, ammonium nitrogen $\left(\mathrm{NH}_{3}-\mathrm{N}\right)$, total phosphorus (TP), chemical oxygen demand $\left(\mathrm{COD}_{\mathrm{Mn}}\right)$, and chlorophyll a (Chla) for February, May, August, and November (in 2011, 2012, and 2013). The analytical methods include the Potassium Persulfate Oxidation-UV Spectrophotometer Method for TN and TP, the Nessler's Reagent Method for $\mathrm{NH}_{3}-\mathrm{N}$, the Potassium Permanganate Titration Method for $\mathrm{COD}_{\mathrm{Mn}}$, and the Spectrophotometer Method for Chla [25]. Unfiltered water samples were used in the TN, TP, and $\mathrm{COD}_{\mathrm{Mn}}$ analysis. Water samples were filtered using Whatman glass microfiber filters (GF/C, pore size $1.2 \mu \mathrm{m}$, Sigma-Aldrich, St. Louis, MO, USA) prior to $\mathrm{NH}_{3}-\mathrm{N}$ and Chla analysis.

Lake water was also sampled in February, May, August, and November of 2014 and 2015 to evaluate effect of harvesting on chemical properties following the same procedure. The lake water was sampled prior to plant sampling at approximately $0.3 \mathrm{~m}$ depth at each site (Figure 1b). Lake water samples of $1000 \mathrm{~mL}$ were collected in plastic bottles and transported to the field station (TLLERS) for chemical analysis.

Contents of TN (plant-N) and TP (plant-P) in plant tissues were analyzed to calculate the amount of nitrogen and phosphorus removed by harvesting. The plant tissues for analysis were randomly collected from the harvested N. peltata. Plant-N and plant-P of the dried plant tissues were analyzed by the $\mathrm{H}_{2} \mathrm{SO}_{4}-\mathrm{H}_{2} \mathrm{O}_{2}$ digestion method and the Mo-Sb colorimetric method, respectively.

\subsection{Assessment Method}

To assess variation in the water quality, the rate of decrease or increase in quality was calculated as follows:

$$
\text { Decrease (Increase) rate of } 2014=\frac{c_{2011}+c_{2012}-2 \times c_{2014}}{c_{2011}+c_{2012}} \times 100 \%
$$

where $c$ is yearly average concentration. The same method was used to calculate decrease (increase) rate of 2015.

Reduction rate of N. peltata coverage was calculated according to May 2013 (before harvest) and June 2014 (one year after harvest) as follows:

$$
\text { Reduction rate }=\frac{\text { Coverage in May of } 2013-\text { coverage in June of } 2014}{\text { coverage in May of } 2013} \times 100 \%
$$


The aforementioned submerged aquatic plants generally obtained their maximum biomass in September, therefore the absolute growth rate (AGR) was calculated according to the changes of biomass from May to September.

$$
\text { Growth rate }=\frac{\text { Biomass in September } 2013-\text { Biomass in May } 2013}{120(\text { days })}
$$

Difference in coverage and biomass of $N$. peltata before and after harvesting as well as between zones, chemical parameters between years, and P. malaianus coverage between $\mathrm{Z} 1$ and $\mathrm{Z} 4$ were compared using one-way analysis of variance (ANOVA) test performed with SPSS version 13.0 software. Differences were considered significant at $p<0.05$.

\section{Results}

\subsection{Variation in Coverage and Biomass of N. peltata}

Coverage of $N$. peltata decreased dramatically in $\mathrm{Z1}, \mathrm{Z2}, \mathrm{Z3}, \mathrm{Z4}$, and $\mathrm{Z} 5$ when the harvesting started in May 2013 (Figure 2a). The harvesting of Z1, Z2, Z3, and Z4 began in May, and most $N$. peltata was already harvested before June. In contrast, the intensive harvesting of N. peltata in Z5 was sustained in May and June, so that the decrease in coverage of $N$. peltata in $Z 5$ was relatively low in June $(58.8 \%)$ compared with that in Z1, Z2, Z3, and Z4. Consequently, the N. peltata coverage in Z5 exhibited another decrease of $54.3 \%$ in July. The harvesting of N. peltata in Z6 ended in the middle of September, so that the coverage showed a dramatic decrease of $54.7 \%$ in September. The observed decrease in N. peltata coverage in October was entirely due to the decay of aquatic plants because harvesting had already been terminated.

In the second year, coverage of N. peltata increased from March to June by $40 \%$ for Z6 and $16 \%$ for $\mathrm{Z} 5$, respectively. In contrast, coverage increased quite low in the other four zones. Actually, there was a dramatic decrease of peak coverage of the six zones in 2014. In May 2015, although N. peltata reached the rapid growth period, the maximum coverage was still lower than $24.6 \%$, indicating that the spread of N. peltata after harvesting was successfully diminished in the following two years. One-way ANOVA statistical analysis showed that there was a significant difference of N. peltata coverage between 2013 and $2014(F=6.63, p=0.01)$ (Table 2).

When the intensive harvest was finished in May, the average biomasses of N. peltata in Z1, Z2, Z3, and $Z 4$ were decreased by $74.5 \%, 73.1 \%, 84.8 \%$ and $68 \%$, respectively (Figure $2 b$ ). However, the biomasses in $\mathrm{Z} 5$ and $\mathrm{Z} 6$ were quite different from those of the other four zones. The average biomass of Z5 decreased extremely slowly after harvest, mainly because harvesting focused on target areas until the floating-leaved vegetation was removed, so the survival area still possessed a relatively high biomass but with low $N$. peltata coverage. By July and August, the average biomass in Z5 $\left(1.23 \mathrm{~kg} \mathrm{~m}^{-2}\right)$ was lower than that in Z6 $\left(1.68 \mathrm{~kg} \mathrm{~m}^{-2}\right)$. There was significant difference of coverage between 2013 and $2014(F=0.54, p=0.47)$. Our findings also suggest that different harvesting dates result in significant spatial differentiation in $N$. peltata coverage and biomass in the lake $(p<0.05$, Table 2). However, no significant difference of biomass was observed between 2013 and $2014(F=0.54, p=0.47)$.

\subsection{Aquatic Plant Community}

Within 20 months after harvest, 10 vegetative species were observed: N. peltata, T. bispinosa, P. malaianus, P. maackianus, $M$. verticillatum, H. verticillata, Vallisneria natans, Ceratophyllum demersum, Charophycea charales, and Elodea nuttallii. No species disappeared, and no new species were observed during the two study years. The frequency of the dominant species (P. malaianus) in Z4 and Z6 was relatively low before harvesting, compared to that in other zones, and the expansion was steady during the growth period after harvesting (Figure 3a). The frequency of $H$. verticillata in Z5 increased dramatically after harvest, reaching a peak value of $80.1 \%$ in October. 


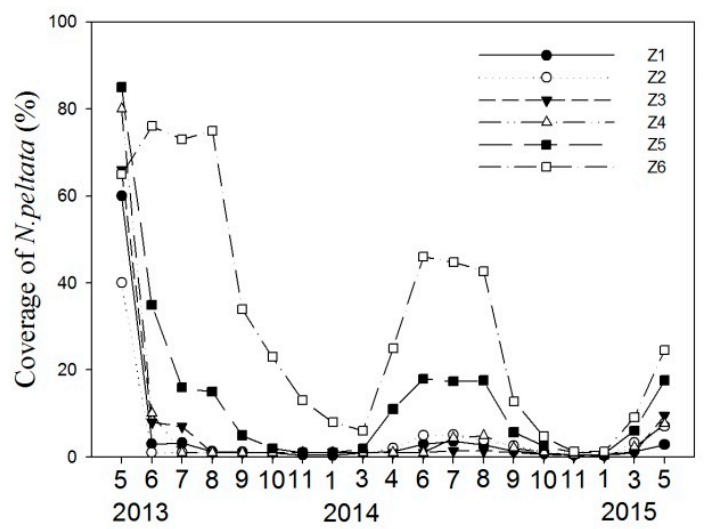

(a)

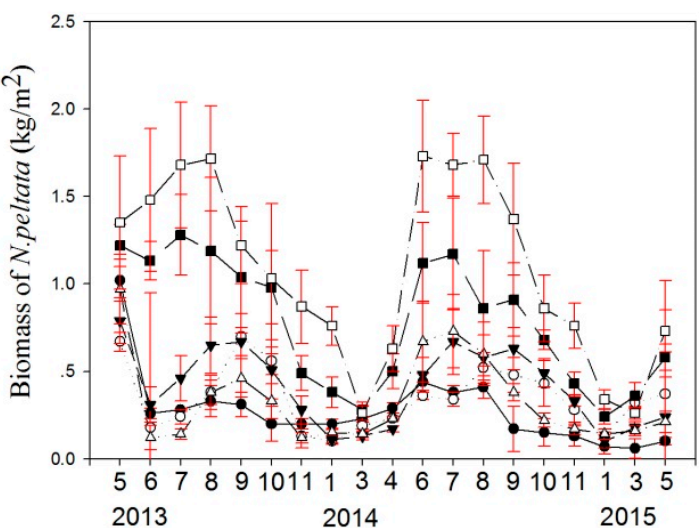

(b)

Figure 2. Variation in N. peltata coverage (a) and biomass (with standard errors) (b) of the six zones (year and month).

Table 2. One way ANOVA analysis of $N$. peltata coverage and biomass between six zones ( $\mathrm{C}$ and $\mathrm{B}$ represent coverage and biomass).

\begin{tabular}{|c|c|c|c|c|c|c|c|c|c|c|}
\hline \multirow{2}{*}{ Zone } & \multicolumn{2}{|c|}{$\mathrm{Z} 2$} & \multicolumn{2}{|c|}{ Z3 } & \multicolumn{2}{|c|}{$\mathrm{Z4}$} & \multicolumn{2}{|c|}{$\mathrm{Z5}$} & \multicolumn{2}{|c|}{ Z6 } \\
\hline & C & B & C & B & C & B & C & B & C & B \\
\hline $\mathrm{Z} 1$ & $\begin{array}{l}F=0.02 \\
p=0.89\end{array}$ & $\begin{array}{l}F=1.32 \\
p=0.26\end{array}$ & $\begin{array}{l}F=0.03 \\
p=0.86\end{array}$ & $\begin{array}{c}F=0.367 \\
p=0.06\end{array}$ & $\begin{array}{l}F=0.11 \\
p=0.74\end{array}$ & $\begin{array}{l}F=0.59 \\
p=0.45\end{array}$ & $\begin{array}{l}F=2.72 \\
p=0.11\end{array}$ & $\begin{array}{c}F=27.78 \\
p=0.01\end{array}$ & $\begin{array}{c}F=14.94 \\
p=0.01\end{array}$ & $\begin{array}{c}F=39.12 \\
p=0.01\end{array}$ \\
\hline $\mathrm{Z} 2$ & & & $\begin{array}{l}F=0.12 \\
p=0.73\end{array}$ & $\begin{array}{l}F=0.90 \\
p=0.35\end{array}$ & $\begin{array}{l}F=0.24 \\
p=0.63\end{array}$ & $\begin{array}{l}F=0.05 \\
p=0.83\end{array}$ & $\begin{array}{l}F=3.74 \\
p=0.06\end{array}$ & $\begin{array}{c}F=22.02 \\
p=0.01\end{array}$ & $\begin{array}{c}F=17.65 \\
p=0.01\end{array}$ & $\begin{array}{c}F=33.75 \\
p=0.01\end{array}$ \\
\hline Z3 & & & & & $\begin{array}{l}F=0.03 \\
p=0.87\end{array}$ & $\begin{array}{l}F=1.02 \\
p=0.32\end{array}$ & $\begin{array}{l}F=2.09 \\
p=0.16\end{array}$ & $\begin{array}{c}F=14.66 \\
p=0.01\end{array}$ & $\begin{array}{c}F=13.34 \\
p=0.01\end{array}$ & $\begin{array}{c}F=24.74 \\
p=0.01\end{array}$ \\
\hline $\mathrm{Z} 4$ & & & & & & & $\begin{array}{l}F=1.42 \\
p=0.24\end{array}$ & $\begin{array}{c}F=19.96 \\
p=0.01\end{array}$ & $\begin{array}{c}F=11.12 \\
p=0.01\end{array}$ & $\begin{array}{c}F=32.01 \\
p=0.01\end{array}$ \\
\hline Z5 & & & & & & & & & $\begin{array}{l}F=5.23 \\
p=0.03\end{array}$ & $\begin{array}{l}F=4.12 \\
p=0.05\end{array}$ \\
\hline
\end{tabular}

The variations in plant biomass were consistent with those in the frequency of occurrence (Figure $3 \mathrm{~b}$ ). The biomass of $H$. verticillata in $\mathrm{Z} 5$ increased from July and reached a peak value of $9.8 \mathrm{~kg} \mathrm{~m}^{-2}$ in October. H. verticillata exhibited the greatest AGR (53.3 $\left.\mathrm{g} \mathrm{day}^{-1} \mathrm{~m}^{-2}\right)$ among the species. The AGR of Potamogeton species in the other zones were comparatively low and varied from $3.3 \mathrm{~g}$ day $^{-1} \mathrm{~m}^{-2}$ to $15.8 \mathrm{~g}$ day $^{-1} \mathrm{~m}^{-2}$.
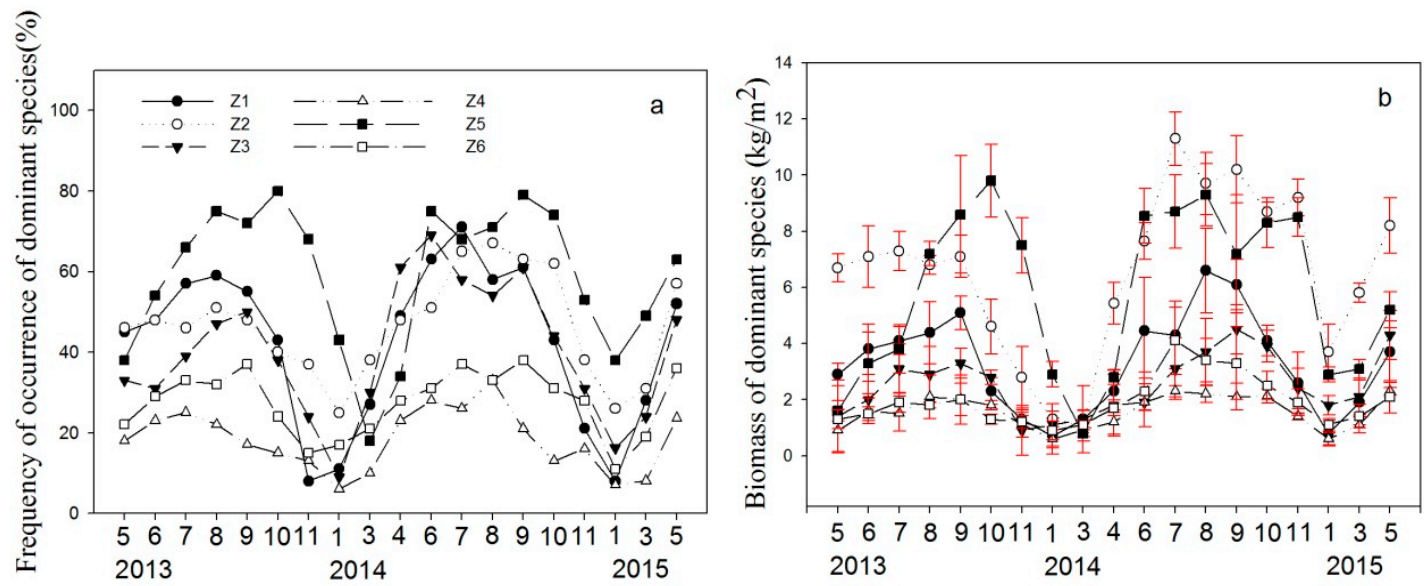

Figure 3. Variation in dominant species occurrence frequency and biomass of each zone. (The dominant species were P. malaianus (Z1, Z3, Z4, and Z6), P. maackianus (Z2), and H. verticillata (Z5).). (a) Frequency of occurrence of dominant species (\%); (b) Biomass of dominant species $\left(\mathrm{kg} / \mathrm{m}^{2}\right)$. 


\subsection{Plant-N and Plant-P}

Removal of a large amount of $N$. peltata would decrease the nitrogen and phosphorus loading in a lake, with the amount of decrease dependent on the plant- $\mathrm{N}$ and plant-P proportions and the amount harvested. Plant-N ranged from $11.6 \mathrm{mg} / \mathrm{g}$ to $16.9 \mathrm{mg} / \mathrm{g}$ with an average of $13.4 \pm 1.6 \mathrm{mg} / \mathrm{g}$ in May, and from $14.2 \mathrm{mg} / \mathrm{g}$ to $15.9 \mathrm{mg} / \mathrm{g}$ with an average of $15.1 \pm 0.6 \mathrm{mg} / \mathrm{g}$ in August. Average plant-N increased $12.8 \%$, but there was no significant difference $(p>0.05, F=6.71)$ between plant- $\mathrm{N}$ in May and August. Plant-P ranged from $1.6 \mathrm{mg} / \mathrm{g}$ to $2.7 \mathrm{mg} / \mathrm{g}$ with an average of $2.0 \pm 0.4 \mathrm{mg} / \mathrm{g}$ in May, and from $1.6 \mathrm{mg} / \mathrm{g}$ to $2.2 \mathrm{mg} / \mathrm{g}$ with an average of $2.0 \pm 0.2 \mathrm{mg} / \mathrm{g}$ in August. There was no significant correlation $(p>0.05)$ or difference $(p>0.05, F=0.02)$ in plant-P between May and August.

\subsection{Water Quality}

Chemical parameters varied with different trends before and after harvesting (Figure 4). Average yearly concentrations of $\mathrm{TN}, \mathrm{NH}_{3}-\mathrm{N}$, and $\mathrm{COD}_{\mathrm{Mn}}$ from 2011 to 2012 were $1.46 \mathrm{mg} \mathrm{L}^{-1}, 0.28 \mathrm{mg} \mathrm{L}^{-1}$, and $3.49 \mathrm{mg} \mathrm{L}^{-1}$, respectively. In 2014, the average yearly concentrations of $\mathrm{TN}, \mathrm{NH}_{3}-\mathrm{N}$, and $\mathrm{COD}_{\mathrm{Mn}}$ decreased by $34.7 \%, 49.3 \%$, and $29.5 \%$, respectively. In 2015 , they decreased by $31.4 \%, 48.3 \%, 21.9 \%$ compared with 2011-2012. The trend was different for TP and Chla. TP decreased by $2.9 \%$ in 2014 , but increased by $22.5 \%$ in 2015, compared to 2011 and 2012. Chl $a$ increased by $29.5 \%$ and $24.4 \%$ in 2014 and 2015 compared with 2011-2012. Statistical analysis between years indicated that there were significant differences for $\mathrm{TN}, \mathrm{NH}_{3}-\mathrm{N}$ and $\mathrm{COD}_{\mathrm{Mn}}$ before and after harvesting. Statistical analysis between years indicated that there were significant differences before and after harvesting for TN, $\mathrm{NH}_{3}-\mathrm{N}$ and $\mathrm{COD}_{\mathrm{Mn}}$ (Table 3).

Table 3. One-way ANOVA analysis of chemical parameters between years.

\begin{tabular}{|c|c|c|c|c|c|c|c|c|c|c|}
\hline \multirow{2}{*}{ Parameters } & \multicolumn{2}{|c|}{$2012 / 2013$} & \multicolumn{2}{|c|}{$2012 / 2014$} & \multicolumn{2}{|c|}{$2012 / 2015$} & \multicolumn{2}{|c|}{$2013 / 2014$} & \multicolumn{2}{|c|}{$2013 / 2015$} \\
\hline & $F$ & $p$ & $F$ & $p$ & $F$ & $p$ & $F$ & $p$ & $F$ & $p$ \\
\hline $\mathrm{TP}$ & 4.72 & 0.03 & 0.15 & 0.70 & 7.19 & 0.01 & 7.04 & 0.01 & 0.02 & 0.89 \\
\hline $\mathrm{TN}$ & 1.8 & 0.19 & 6.99 & 0.01 & 5.90 & 0.02 & 16.40 & 0.01 & 15.15 & 0.01 \\
\hline $\mathrm{NH}_{3}-\mathrm{N}$ & 1.28 & 0.26 & 20.20 & 0.01 & 19.64 & 0.01 & 28.93 & 0.01 & 28.35 & 0.01 \\
\hline $\mathrm{COD}_{\mathrm{Mn}}$ & 0.76 & 0.39 & 23.49 & 0.01 & 26.01 & 0.01 & 27.91 & 0.01 & 30.42 & 0.01 \\
\hline Chla & 13.14 & 0.01 & 4.04 & 0.049 & 2.23 & 0.14 & 5.14 & 0.03 & 5.34 & 0.03 \\
\hline
\end{tabular}



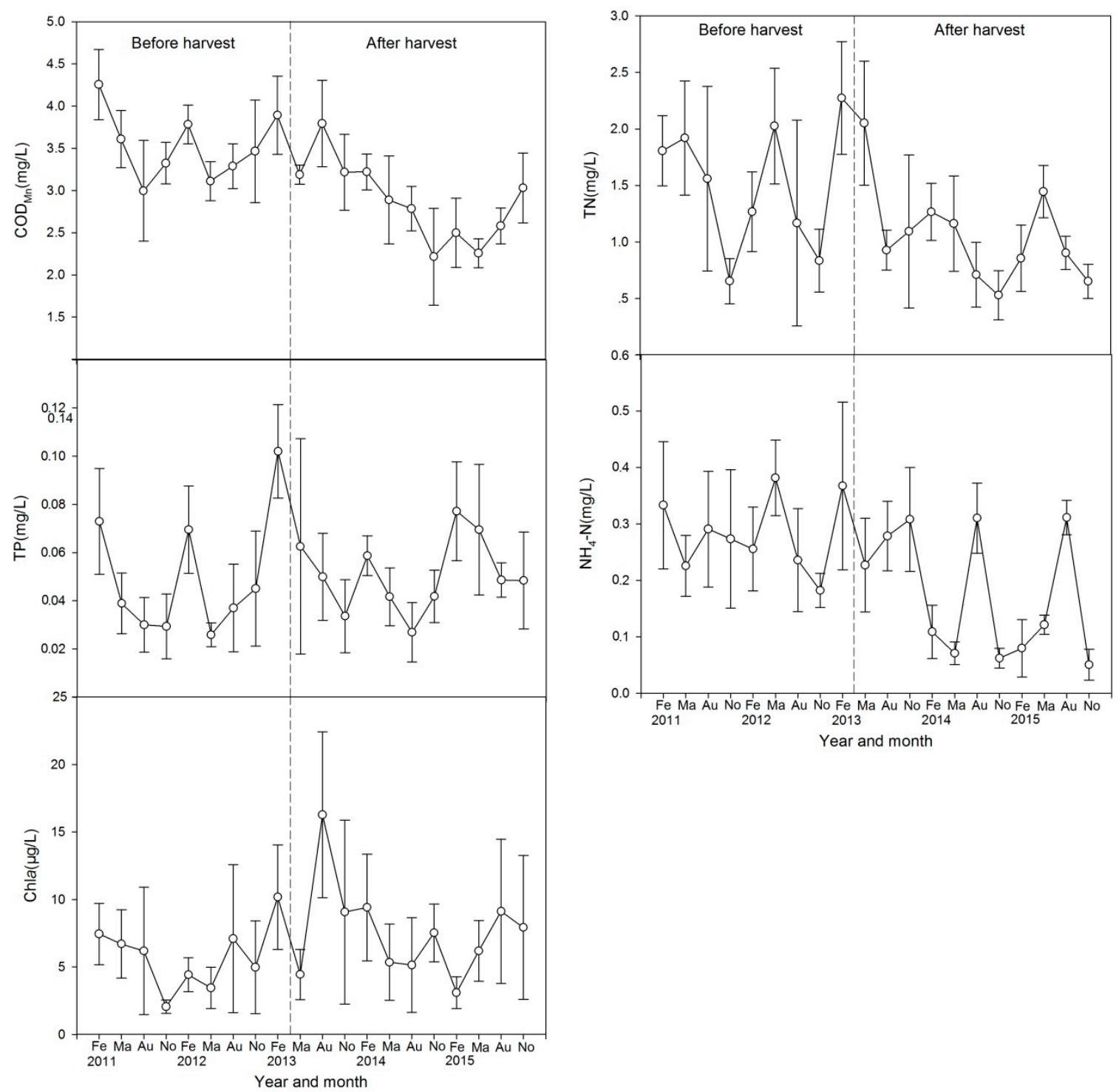

Figure 4. Variation of average water quality of the six zones in February (Fe), May (Ma), August (Au), and November (No) from 2011 to 2015 (with standard error).

\section{Discussion}

\subsection{Effect of Harvest on Water Quality}

Enrichment of nitrogen and phosphorus would accelerate the eutrophication of lakes. Plant harvesting has been widely used to reduce nitrogen and phosphorus nutrient in lakes and wetlands, since it directly removes the nutrient stocks held in plant tissues [26-28]. N. peltata plays an important role in the nutrient stocks of lake waters [16]. According to Wu et al. [29], the total nitrogen and phosphorus were stored with a high content in the active sediments of Lake Taihu. In this study, the harvested species was floating-leaved N. peltata, which probably uptake nutrients via root systems [16] and release them into water column [17]. In contrast, the nutrient utilization by submerged plants can significantly affect the trophic status and ecosystem function of shallow lakes [30]. The root system of $H$. verticillate, which increased notably after harvesting, is relatively underdeveloped and a significant proportion of nutrient requirement can be absorbed exclusively from the water [31]. The increase of coverage and spread of submerged plants resulted by harvesting of floating-leaved species could improve water quality of the lake. Furthermore, approximately $2.2 \times 10^{4}$ tons of $N$. peltata (wet weight) was removed from the lake water in this study, and more than 26 tons of nitrogen and 4 tons of phosphorus were removed from the ecosystem, according to 
the plant-N and plant-P contents. Statistical results showed that harvesting of the floating-leaved N. peltata would be beneficial for $\mathrm{TN}, \mathrm{NH}_{3}-\mathrm{N}$, and $\mathrm{COD}_{\mathrm{Mn}}$ reduction in the lake.

However, harvesting of aquatic plants does not always improve water quality. In this study, the removal amount of TN and TP was quite small compared to the annual areal nitrogen (10,402 tons) and phosphorus (431 tons) load [32]. Harvesting would be positive in diminishing the overgrowth of floating-leaved species, which have already impacted other aquatic communities and impaired the services function of lakes, such as in east of Lake Taihu. Under other conditions, the fact that aquatic plant could restrict phytoplankton, and supply food, shelter, and habitat for a diversity of organisms should be fully considered [33-35]. In large shallow lakes, harvesting of floating-leaved plants would also enhance wave conditions, by weakening the hydraulic resistance by plants [36,37], therefore increasing the risk of sediments phosphorus release [38]. Furthermore, cyanobacteria were mostly clustered in the northern and western areas of Lake Taihu [39], but drifted to the eastern part of the lake at times due to the southwest wind. Substantially more free lake surface was exposed after harvesting of the floating-leaved N. peltata, which was beneficial for the drift of the cyanobacteria and increased the Chla concentration.

\subsection{Effect of Harvest on the Regrowth of N. peltata}

The response of N. peltata differed widely among the various harvest dates in our study. N. peltata harvested in May effectively inhibited the coverage in the next year, during which the propagation and expansion were limited (Figure 2b). In contrast, harvesting that commenced in September demonstrated very limited restriction on $N$. peltata coverage. Different harvesting date results in significant spatial differentiation in N. peltata coverage and biomass in the lake $(p<0.05$, Table 2$)$. However, no significant difference of biomass was observed between 2013 and 2014 ( $F=0.54, p=0.47)$. The reduction rate of $N$. peltata coverage for Z1, Z2, Z3, Z4, and Z5 ranged from $78.8 \%$ to $95.1 \%$, compared with $29.2 \%$ for Z6. Similar findings that the effectiveness of mechanical control depends on the date of the harvest have been reported [40]. Harvesting of Elodea nuttallii before the end of June will necessitate a second harvest later in the season, but harvesting before September would limit the amount of biomass [7]. For the floating-leaved Ranunculus peltatus, a single harvest is most efficient if performed in April or May since its flowering is totally inhibited by the harvest [6].

The coverage of N. peltata has quickly expanded in Lake Taihu in recent years because the buoyancy of the $N$. peltata seeds is greater than that of most of the submerged species [41]. Seed buoyancy for approximately two days is long enough for these seeds to disperse over great distances, even with a moderate water flow, and this dispersal may promote expansion of the N. peltata colony [15]. Harvesting in September allowed enough time for the N. peltata fruits to set in July and then release the seeds for the subsequent year's recruitment. Furthermore, in contrast with other plant parts, the roots of N. peltata had a very high percentage of ash in June when the root biomass is the lowest; in winter, the roots have the highest absolute and relative biomass to ensure the extension of rhizomes and stolons, which are also an important means of reproduction for N. peltata populations. Conversely, harvesting in early May could destroy and impede the N. peltata propagation process, which would limit the expansion of this species in the following year. According to our results, harvesting for N. peltata control is most efficient if performed in May, with the harvesting plan depending on the required degree of regulation.

\subsection{Spatial Differentiation in Aquatic Plant Coverage after Harvesting}

Even careful harvesting protocols may cause the complete loss of vegetation in an area of water disturbed by strong waves where the positive feedback of the increasing turbidity will lead to a further decrease in submerged vegetation growth. This study included an extensive water surface area of $196 \mathrm{~km}^{2}$, across which the hydrodynamic conditions and intensity of the wave disturbance exhibited great spatial variation [19]. Z1 and Z4 are in the open lake, which is disturbed frequently and intensively by wind-induced waves. The colonization of dense floating-leaved N. peltata in those areas could disperse wave propagation, dissipate wave energy, and reduce flow velocity. Removal 
of $N$. peltata could eliminate wave dissipation and result in the exposure of submerged vegetation to frequent waves. Therefore, the extension of P. malaianus was much slower in $\mathrm{Z} 4$. Z1 also suffered from strong wave disturbance, but the area was already covered with a higher density of $P$. malaianus before harvesting (with a biomass of $2.9 \mathrm{~kg} \mathrm{~m}^{-2}$ and coverage of $45.0 \%$ in May 2013) than that of Z4 (with a biomass of $0.9 \mathrm{~kg} \mathrm{~m}^{-2}$ and coverage of $18.6 \%$ in May of 2013). After harvesting, the difference in P. malaianus coverage between $\mathrm{Z} 1$ and $\mathrm{Z} 4$ was significant $(p=0.028, F=791.0)$. In general, harvesting in different wave disturbance conditions would have different effects on the expansion of submerged vegetation, depending on the vegetation's initial density.

\subsection{Response of Submerged Plants to Harvesting}

In eutrophic lakes, for example, small and slow-growing aquatic plant species have often disappeared, whereas robust and fast-growing species capable of forming a canopy just below the water surface have survived [42]. In this study, $H$. verticillata exhibited high plasticity and adaptability, which enabled it to easily form dense mat canopies that displaced other plants and improved its expansion capacity. The coverage of $H$. verticillata in Z5 increased dramatically from $38 \%$ in May to $81 \%$ in October. In contrast, coverage of P. malaianus, which is the most dominant species in Lake Taihu, increased relatively slowly.

Previous studies have shown that $H$. verticillata is highly competitive [43,44]. Compared with Potamogeton and Myriophyllum species, $H$. verticillata had higher numbers of shoots and roots, which contribute to its ability to disperse and establish in novel sites [45]. In fact, mechanical harvesting helps propagate $H$. verticillata by causing the release of a variety of vegetative plant parts, including entire plants, rhizomes, stolons, tubers, turions, and, more frequently, fragments [46]. It is reported that fragments of $H$. verticillata have higher colonization and regeneration abilities [47]. This advantage would facilitate the success of this species more than that of Potamogeton species and Myriophyllum species. Based on our observations, the available ecological niches following harvest of $N$. peltata were quickly occupied by H. verticillata in Z5. Although H. verticillata was not dominant yet in the other five zones, its frequency of occurrence increased notably during the study.

\section{Conclusions}

In contrast to earlier research on aquatic plant harvests and their effects, our study: (1) focused on a large area $\left(196 \mathrm{~km}^{2}\right)$ where $N$. peltata was mechanically harvested in a shallow lake; (2) examined the response of N. peltata and the submerged vegetation community to harvesting; and (3) evaluated the effect of harvesting on nutrient removal. Our findings indicate that harvesting for N. peltata control is most efficient if performed in May because this could prevent N. peltata flowering and impede its reproduction via the extension of rhizomes and stolons. Hydrilla verticillata could quickly invade and occupy the available ecological niche after N. peltata removal. In areas that are disturbed by wind-induced waves, frequent and thorough removal of $N$. peltata would intensify the wave disturbance, thereby increasing the difficulties of seed settling and germination. Therefore, the recovery of submerged plants after N. peltata harvesting became slow and uncertain in these areas. Harvesting a large amount of $N$. peltata has a positive effect on $\mathrm{TN}, \mathrm{NH}_{3}-\mathrm{N}$, and $\mathrm{COD}_{\mathrm{Mn}}$ control but can lead to different consequences (e.g., increase in TP and algal concentration).

Author Contributions: Conceptualization, J.Z. and W.H.; Methodology, J.Z. and W.H.; Software, J.Z.; Validation, J.Z., Z.P. and X.L.; Formal Analysis, J.Z.; Investigation, J.Z., Z.P., X.L., J.D. and Y.Z.; Writing-Original Draft Preparation, J.Z.; Writing-Review \& Editing, J.Z., Z.P., X.L., J.D. and Y.Z.

Funding: This research was jointly funded by the Major Science and Technology Program for Water Pollution Control and Treatment (No. 2017ZX07205002 and No. 2018ZX07208008), the Natural Science Foundations of China (No. 51609235) and Jiangsu Province (No. BK20151063 and No. BK20151064), and the Foundation of NIGLAS (Y8SL011002).

Acknowledgments: Two anonymous reviewers gave valuable comments on the manuscript. The authors are grateful to Xiaohua Zhu and Marieke A. Frassl for editing the manuscript prior to submission.

Conflicts of Interest: The authors declare no conflict of interest. 


\section{References}

1. Vereecken, H.; Baetens, J.; Viaene, P.; Mostaert, F.; Meire, P. Ecological management of aquatic plants: Effects in lowland streams. Hydrobiologia 2006, 570, 205-210. [CrossRef]

2. Li, C.; Wang, B.; Ye, C.; Ba, Y. The release of nitrogen and phosphorus during the decomposition process of submerged macrophyte (Hydrilla verticillata Royle) with different biomass levels. Ecol. Eng. 2014, 70, 268-274. [CrossRef]

3. Han, H.; Weiping, H.; Shuijing, Z. Modelling nitrogen and phosphorus transfer in Potamogeton malaianus Miq. decompostion. Environ. Sci. 2010, 31, 1483-1488. (In Chinese)

4. Evans, J.M.; Wilkie, A.C. Life cycle assessment of nutrient remediation and bioenergy production potential from the harvest of hydrilla (Hydrilla verticillata). J. Environ. Manag. 2010, 91, 2626-2631. [CrossRef] [PubMed]

5. Caffrey, J.M.; Barrett, R.R.F.; Ferreira, M.T.; Moreira, T.S.; Murphy, K.J.; Wode, P.M. Integrated submerged aquatic vegetation mamagement in an urban New Zealand rive. Hydrobiologia 1999, 415, 235-241.

6. Garbey, C.; Thiébaut, G.; Muller, S. Impact of manual spring harvesting on the regrowth of a spreading aquatic plant: Ranunculus peltatus SCHRANK. Arch. Hydrobiol. 2003, 156, 271-286. [CrossRef]

7. Nino, F.D.; Thiébaut, G.; Muller, S. Response of Elodea Nuttallii (Planch.) H. St. John to manual harvesting in the North-East of France. Hydrobiologia 2005, 551, 147-157. [CrossRef]

8. Xu, W.; Hu, W.; Deng, J.; Zhu, J.; Li, Q. Effects of harvest management of Trapa bispinosa on an aquatic macrophyte community and water quality in a eutrophic lake. Ecol. Eng. 2014, 64, 120-129. [CrossRef]

9. Van Nes, E.H.; van den Berg, M.S.; Clayton, J.S.; Coops, H.; Scheffer, M.; van Ierland, E. A simple model for evaluating the costs and benefits of aquatic macrophytes. Hydrobiologia 1999, 415, 335-339. [CrossRef]

10. Van Nes, E.H.; Scheffer, M.; van den Berg, M.S.; Coops, H. Aquatic macrophytes: Restore, eradicate or is there a compromise? Aquat. Bot. 2002, 72, 387-403. [CrossRef]

11. Mitsch, W.J.; Day, J.W., Jr. Thinking big with whole-ecosystem studies and ecosystem restoration-A legacy of H.T. Odum. Ecol. Model. 2004, 178, 133-155. [CrossRef]

12. Chapin, F.S.; Zavaleta, E.S.; Eviner, V.T.; Naylor, R.L.; Vitousek, P.M.; Reynolds, H.L.; Hooper, D.U.; Lavorel, S.; Sala, O.E.I.; Hobbie, S.E.; et al. Consequences of changing biodiversity. Nature 2000, 405, 234-242. [CrossRef] [PubMed]

13. Dong, B.; Qin, B.; Gao, G.; Cai, X. Submerged macrophyte communities and the controlling factors in large, shallow Lake Taihu (China): Sediment distribution and water depth. J. Great Lakes Res. 2014, 40, 646-655. [CrossRef]

14. Li, K.-Y.; Liu, Z.-W.; Guan, B.-H. Effects of nutrient levels in surface water and sediment on the growth of the floating-leaved macrophyte Trapa maximowiczii: Implication for management of macrophytes in East Bay of Lake Taihu, China. Limnology 2009, 11, 95-101. [CrossRef]

15. Huang, W.; Chen, K.; Shi, X.; Ren, K.; Li, W. The contribution of seeds to the recruitment of a Nymphoides peltata population. Limnologica 2014, 44, 1-8. [CrossRef]

16. Marion, L.; Paillisson, J.-M. A mass balance assessment of the contribution of floating-leaved macrophytes in nutrient stocks in an eutrophic macrophyte-dominated lake. Aquat. Bot. 2003, 73, 249-260. [CrossRef]

17. Lu, J.; Bunn, S.E.; Burford, M.A. Nutrient release and uptake by littoral macrophytes during water level fluctuations. Sci. Total Environ. 2018, 622-623, 29-40. [CrossRef] [PubMed]

18. Zhai, S.; Hu, W.; Zhu, Z. Ecological impacts of water transfers on Lake Taihu from the Yangtze River, China. Ecol. Eng. 2010, 36, 406-420. [CrossRef]

19. Wu, T.; Qin, B.; Zhu, G.; Zhu, M.; Li, W.; Luan, C. Modeling of turbidity dynamics caused by wind-induced waves and current in the Taihu Lake. Int. J. Sediment Res. 2013, 28, 139-148. [CrossRef]

20. Li, Z.; Xu, J.; Cao, T.; Ni, L.; Xie, P. Adaptive responses of a floating-leaved macrophyte, Nymphoides peltata, to a terrestrial habitat. J. Freshw. Ecol. 2010, 25, 481-486. [CrossRef]

21. Environment Agency. Threatened Wildlife of Japan-Red Data Book, 2nd ed.; Japan Wild life Research Center: Tokyo, Japan, 2002.

22. Larson, D. Growth of three submerged plants below different densities of Nymphoides peltata (S. G. Gmel.) Kuntze. Aquat. Bot. 2007, 86, 280-284. [CrossRef]

23. Darbyshire, S.J.; Francis, A. The biology of invasive alien plants in Canada. 10. Nymphoides peltata (S. G. Gmel.) Kuntze. Can. J. Plant Sci. 2008, 88, 811-829. [CrossRef]

24. Child, L.; Brock, J.H.; Brundu, G.; Prach, K.; Pyšek, K.; Wade, P.M.; Williamson, M. Plant invasions: Ecological threats and management solutions. In the Evaluation and Management of Aquatic Weeds in New Zealand; Champion, P.D., Clayton, J.S., Eds.; Backhuys: Leiden, The Netherlands, 2003; pp. 429-434. 
25. Jin, X.; Tu, Q. Criterion to Lake Eutrophication Survey; China Environmental Science Press: Beijing, China, 1999; p. 317.

26. Wang, C.-Y.; Sample, D.J.; Day, S.D.; Grizzard, T.J. Floating treatment wetland nutrient removal through vegetation harvest and observations from a field study. Ecol. Eng. 2014, 78, 15-26. [CrossRef]

27. Hu, L.; Hu, W.; Deng, J.; Li, Q.; Gao, F.; Zhu, J.; Han, T. Nutrient removal in wetlands with different macrophyte structures in eastern Lake Taihu, China. Ecol. Eng. 2010, 36, 1725-1732. [CrossRef]

28. Zhu, J.; Hu, W.; Hu, L.; Deng, J.; Li, Q.; Gao, F. Variation in the efficiency of nutrient removal in a pilot-scale natural wetland. Wetlands 2012, 32, 311-319. [CrossRef]

29. Wu, T.; Qin, B.; Brookes, J.D.; Yan, W.; Ji, X.; Feng, J. Spatial distribution of sediment nitrogen and phosphorus in Lake Taihu from a hydrodynamics-induced transport perspective. Sci. Total Environ. 2019, 650, 1554-1565. [CrossRef]

30. Blindow, I.; Hargeby, A.; Andersson, G. Seasonal changes of mechanisms maintaining clear water in a shallow lake with abundant. Aquat. Bot. 2002, 72, 315-334. [CrossRef]

31. Langeland, K.A. Hydrilla verticillata (L.f.) Royle (Hydrocharitaceae), "the perfect aquatic weed". Castanea 1996, 61, 293-304.

32. Zhu, J.G.; Liu, X.; Deng, J.C.; Peng, J.X.; Zhang, H.T. Pollutant transport rates in the rivers around western Lake Taihu. J. Lake Sci. 2018, 30, 1509-1517.

33. Carpenter, S.R.; Lodge, D.M. Effects of submersed macrophytes on ecosystem processes. Aquat. Bot. 1986, 3-4, 341-370. [CrossRef]

34. Rybicki, N.B.; Landwehr, J.M. Long-term changes in abundance and diversity of macrophyte and waterfowl populations in an estuary with exotic macrophytes and improving water quality. Limnol. Oceanogr. 2007, 52, 1195-1207. [CrossRef]

35. Zhu, J.Y.; Liu, B.; Wang, J.; Gao, Y.L.; Wu, Z.B. Study on the mechanism of allelopathic influence on cyanobacteria and chlorophytes by submerged macrophyte (Myriophyllum spicatum) and its secretion. Aquat. Toxicol. 2010, 98, 196-203. [CrossRef] [PubMed]

36. Paudel, R.; Grace, K.; Galloway, S.; Zamorano, M.; Jawitz, J. Effect of hydraulic resistance by vegetation on stage dynamics of a stormwater treatment wetland. J. Hydrol. 2013, 484, 74-85. [CrossRef]

37. Wang, P.F.; Wang, C. Numerical model for flow through submerged vegetation regions in a shallow lake. J. Hydrodyn. 2011, 23, 170-178. [CrossRef]

38. Xu, G.; Sun, Z.; Fang, W.; Liu, J.; Xu, X.; Lv, C. Release of phosphorus from sediments under wave-induced liquefaction. Water Res. 2018, 144, 503-511. [CrossRef] [PubMed]

39. Duan, H.; Ma, R.; Xu, X.; Kong, F.; Zhang, S.; Kong, W.; Hao, J.; Shang, L. Two-decade reconstruction of algal blooms in China's Lake Taihu. Environ. Sci. Technol. 2009, 43, 3522-3528. [CrossRef]

40. Newman, J. Nuttall's Pondweed; Centre for Ecology \& Hydrology: Bailrigg, UK, 2001; p. 28.

41. Boedeltje, G.; Bakker, J.P.; Bekker, R.M.; Groenendael, J.M.V.; Soesbergen, M. Plant dispersal in a lowland stream in relation to occurrence and three specific life-history traits of the species in the species pool. J. Ecol. 2003, 91, 855-866. [CrossRef]

42. Sand-Jensen, K.; Riis, T.; Vestergaard, O.L.E.; Larsen, S.E. Macrophyte decline in Danish lakes and streams over the past 100 years. J. Ecol. 2000, 88, 1030-1040. [CrossRef]

43. Sousa, W.T.Z. Hydrilla verticillata (Hydrocharitaceae), a recent invader threatening Brazil's freshwater environments: A review of the extent of the problem. Hydrobiologia 2011, 669, 1-20. [CrossRef]

44. Mony, C.; Koschnick, T.J.; Haller, W.T.; Muller, S. Competition between two invasive Hydrocharitaceae (Hydrilla verticillata (L.f.) (Royle) and Egeria densa (Planch)) as influenced by sediment fertility and season. Aquat. Bot. 2007, 86, 236-242. [CrossRef]

45. Umetsu, C.A.; Evangelista, H.S.B.A.; Thomaz, S.M. The colonization, regeneration, and growth rates of macrophytes from fragments: A comparison between exotic and native submerged aquatic species. Aquat. Ecol. 2012, 46, 443-449. [CrossRef]

46. Riis, T.; Sand-Jensen, K.A.J. Dispersal of plant fragments in small streams. Freshw. Biol. 2006, 51, 274-286. [CrossRef]

47. Silveira, M.J.; Thomaz, S.M.; Mormul, R.P.; Camacho, F.P. Effects of desiccation and sediment type on early regeneration of plant fragments of three species of aquatic macrophytes. Int. Rev. Hydrobiol. 2009, 94, 169-178. [CrossRef] 